\title{
Study on Development Direction of University Teachers Based on Scholarship of Teaching
}

\author{
Qing Song \\ School of Foreign Languages, Kunming University,Kunming,China
}

\begin{abstract}
Recently, the actual situation of university education has deviated from the essence of university teaching, and the quality of higher education is a cause for concern. Therefore, it is necessary for university teachers to deeply understand the connotation of scholarship of teaching, reexamine and rethink their own teaching. Firstly, from the perspective of scholarship of teaching, the current development situation of university teachers is analyzed, and then the internal and external causes are put forward. Finally, measures to realize and guarantee the development direction of university teachers are proposed from two aspects of individual and organizational system.
\end{abstract}

Keywords: scholarship of teaching; university teachers; development direction; realizing measures

\section{Introduction}

At present, our country has successively promulgated several relevant policy documents such as "several opinions on strengthening higher school undergraduate teaching work and improving the teaching quality" and "guidance for deepening the reform of teachers' employment system of colleges and universities directly under the Ministry of Education". Furthermore, more than thirty "university teachers' teaching development centers" have been set up. Nowadays, the higher education teaching is attached great importance by relevant state departments ${ }^{[1]}$. However, the actual situation of recent university education has deviated from the essence of university teaching and learning. As a result, the quality of higher education is deteriorating, causing for concern. As the key to the development of higher education, it is necessary for university teachers to balance the relationships among university teaching, scientific research and social service, deeply understand the connotation of scholarship of teaching and learning, as well as clear the direction of their professional development.

Therefore, through analyzing the connotation of scholarship of teaching as well as the development situation of university teachers, this article explores the important causes for the development situation from the perspective of scholarship of teaching and proposes the development direction of university teachers and corresponding realization paths.

\section{The connotation of scholarship of teaching}

Domestic and foreign scholars conduct extensive research on connotation of scholarship of teaching. In the 1990s, the former chairman of the American Carnegie Association for the Teaching Advancement, Ernest Boyer, firstly put forward the concept of "scholarship of teaching" in his special report of "Academic reflection - The focus of the work professor". This report focused on reflecting the declination in quality of undergraduate teaching and narrow teachers evaluation criteria issues and so on $^{[2]}$. Subsequently, Lee Shulman made a further expansion of the connotation, who thought that teaching should be open, by peer evaluation and could promote the development of the academic community ${ }^{[3]}$. R Rice believed that scholarship of teaching should include at least three aspects, containing summarized comprehensive ability, pedagogical knowledge and learning ability ${ }^{[4]}$. McKinney summarized several different definitions about scholarship of teaching on the basis of predecessors' research ${ }^{[5]}$. Compared with foreign countries, scholarship of teaching theory in China started late ${ }^{[6-10]}$. Liu Guilian put forward that scholarship of teaching included mature professional knowledge and professional skills, good communication and cooperation ability, innovation consciousness and innovation ability, as well as continuous learning and research ability ${ }^{[11]}$. Yao Limin proposed that scholarship of teaching was university teachers' specialized knowledge about teaching, reflecting in the deeply understanding of teaching, comprehensive knowledge, superb skills and excellent results four aspects ${ }^{[12]}$. Wang Guilin believed that scholarship of teaching should contain knowledge about teaching methods and the capability of spreading and creating knowledge ${ }^{[13]}$.

On the basis of the above researches, this paper argues that, we must admit that teaching is one of the academic types before defining the scholarship of teaching. It is systematic and specialized knowledge, being not only intellectual activity, but also creative activity. The connotation can be reflected in the following four aspects: 1) Teachers, the research subject of scholarship of teaching, should have comprehensive knowledge of their professional field, which is the study base of teaching as an academic activity; and teachers' professional knowledge not only includes professional knowledge in the field of subject, but also includes professional knowledge in the field of education. 2) Teach- 
ers need to form a superb professional teaching ability gradually in practice of teaching, which is a necessary formation process of scholarship of teaching. A scientific and reasonable teaching plan is developed according to the characteristics of students to stimulate students' creativity, and reflection and peer reviews are needed to form a system of teaching theory. 3) Teachers should be able to creatively teach students how to learn, and it is the purpose of scholarship of teaching. University education is aimed at improving the quality of the nation, imparting knowledge and training successors of country, so university teachers should teach students knowledge and training applied talents by their creative teaching methods. 4) Scholarship of teaching finally forms a systematic and special knowledge system about teaching, and this is the final results of scholarship of teaching, a kind of public resources for reference. Above all, on the basis of teachers' comprehensive grasp of professional knowledge, scholarship of teaching is a systematic and special academic activity about teaching through constant practice and peer evaluation, forming excellent and professional teaching ability.

\section{Analysis of university teachers' development situa- tion and its reasons based on scholarship of teaching}

\subsection{The development situation of university teachers}

At present, compared with the developed countries, the university teachers' development in our country is still at a low level. Development problems of university teachers have gradually become the bottleneck of popularization of higher education and improvement of teaching quality. Current situation of the development of university teachers can be summed up in three aspects as follows:

(1) University teachers have a vague concept of "scholarship of teaching", and their teaching ability is not high.

Because scholarship of teaching in China started late, so the majority of university teachers have not yet understood its profound meaning and scope. Common understanding of the "academic" is too narrow to limit the concept of academic research to knowledge production, putting the knowledge spread out. Moreover, academic is regarded as academic papers and monographs, and university teaching is regarded as skills, ignoring teaching academic problems such as "why and how to impart knowledge". In addition, due to the expansion of higher education scale, massive young teachers joined the university faculty. However, most of them lack the ability to manage the classroom and to teach students in accordance with their aptitude, resulting in low quality of teaching. The teaching ability of university teachers needs to be improved as soon as possible ${ }^{[14]}$.

(2) The development of university teachers presents the tendency of "heavy science, light teaching".

Currently, the phenomenon of "attaching great importance to scientific research, project-based" universally exists, and some teachers even regard teaching as a burden.
Concerned investigation demonstrates that the amount of professional research papers and research awards that university teachers achieved is greater than the number of educational reform and teaching achievement prizes. And in terms of distribution of teaching time, time of teaching research and guiding students takes up a smaller proportion ${ }^{[15]}$. University teachers spend a lot of time to write papers and monographs, as a result, they invest less and less time in teaching research, directly reducing the teaching time and effort and resulting in a decline in the quality of teaching.

(3) University teachers ignore the teaching reflection and peer communication.

University teachers lack of consciousness of reflection on the teaching activities, regarding it as a repetitive task. When they encounter problems, they seldom go to explore fundamental cause of the problem, because they don't think it is worth reflection and study. In return, they put more energy into scientific research. At the same time, due to the partial understanding of their own development, university teachers hold the opinion that the education ability is accumulated and improved in practice, ignoring the importance of theoretical research and rational reflection. In addition, the communication between the university teachers is often limited to specific academic research direction of a small group of people. Also, because the objective existence of academic status and level, it is hard for university teachers' communication to be equal, which eventually lead to the lack of communication between the university teachers.

\subsection{The reason analysis of university teachers' devel- opment situation}

According to the comprehensive analysis of the current development situation of university teachers based on scholarship of teaching, this article summarizes the reasons from two aspects of internal causes and external causes.

(1)Internal causes---university teachers

As main objects of scholarship of teaching, university teachers pay less and less attention to teaching activities. Some teachers don't have correct understanding of the academic characteristics of teaching, and just treat it as a kind of repetitive work, playing down the academic value of teaching; Some teachers always focus on their own professional field, and never take teaching as a problem; The other teachers can't properly handle the relationship between teaching and science under pressure of promotion and assessment, and usually put the most energy into scientific research, weakening the academic position of teaching.

(2) External causes----the influence of nation, society and school

The external environment is the other important cause of the current development situation of university teachers. At the national level, the country pays less attention to the academic and ignores strengthening of the teachers' quality and continued ascension. As a safeguard mechanism of the development of university teachers, the country gives insufficient attention and humanistic concern, seriously hinder- 
ing the development of university teachers. At the social level, most people's understanding of the academic is relatively narrow, and they can't face up to the academic characteristics of teaching. Also, the social evaluation criterion of university teachers is still a research level, less considering teaching level. This kind of social cognition and evaluation is false and restricts the development of university teachers. At the school level, there exits serious "heavy science, light teaching" phenomenon in selection and appointment of university teachers, even the number of papers published being the sole criterion for evaluation. As a result, university teachers can't get fair and reasonable evaluation in terms of teaching. At last, this phenomenon will lead to the frustration of teachers, which greatly affects the teachers' enthusiasm engaged in teaching. In addition, preservice training and in-service training of university teachers become a mere formality, exiting problems of single training method and content and so on ${ }^{[16]}$.

\section{The development direction of university teachers and its realizing measures based on scholarship of teaching}

Facing such serious situation, it is the high time to clear the development direction of university teachers and take measures to prompt and realize this direction.

\subsection{The developing direction of university teachers based on scholarship of teaching}

The core of the development of university teachers is to develop "teaching" to promote the true return of university teaching. Thus, based on this core, the development direction of university teachers can be summarized in the following three aspects: to promote the development of scholarship of teaching, train creative students and improve teaching quality. Research on scholarship of teaching is one of the directions of the university teachers' future development, which can deepen the study of scholarship of teaching, and also raise the level of teaching in turn. Moreover, training creative students and improving teaching quality are not only the goals of university teaching, but also the guiding lights of university teachers' development.

\subsection{Realizing measures}

According to the internal and external causes of university teachers' development situation based on scholarship of teaching, this paper presents some measures to achieve the development direction of university teachers from the individual and organizational levels.

\section{(1) Internal aspects}

The development of university teachers mainly depends on the faculty's own efforts. It is the key to promote the development of university teachers to correctly understand and grasp the academic characteristics of university teaching. First of all, university teachers should be aware of the academic characteristics and important value of teaching, and take it as the main way of teachers' development. Sec- ondly, university teachers should consciously strengthen academic research on teaching, research and reflect on teaching objects, content, methods and management aspects with scientific and rational attitude. And then they should continue to carry out comparative analysis of the theory and practice to enhance the academic characteristics of university teaching. Finally, they should constantly strengthen their moral cultivation, eliminate adverse phenomenon such as academic fraud, and cultivate pragmatic, pioneering and innovative spirit actively.

(2) The organization and system guarantee

It is inseparable from external organization and system guarantee to promote the development of university teachers in the right direction. On the one hand, universities should actively create an atmosphere of scholarship of teaching first, establishing academic status of teaching fundamentally. And then universities should encourage teachers to conduct research and actively carry out exchanges and reflection on teaching. In teacher training, we should avoid single training purpose of enhancing scientific literacy, and eliminate formal training. And more training programs that conducive to enhance teaching standards should be designed and new teaching ideas, new methods and new technologies should be introduced. On the other hand, the system and standards of academic assessment and teachers' evaluation should be sounded by taking the quantifiable academic standards of scholarship of teaching into the basic academic evaluation project. This method can make the academic evaluation of universities based on the double standards of teaching and science. Meantime, in order to make a comprehensive evaluation on the level of university teachers, it is necessary to reform the current evaluation criteria, abandon the traditional single standard of scientific paper number and scientific research awards, and take knowledge discovery, synthesis and application of teaching into evaluation system.

\section{Conclusions}

In summary, the idea of scholarship of teaching is of great significance for development of university teachers, which can prompt the university teachers to re-examine and reflect their own teaching. Based on the perspective of scholarship of teaching, this paper analyzes the development situation of university teachers as well as the internal and external causes of the situation. And finally we propose measures to realize the development direction of university teachers from the individual and organizational levels. It still needs further research on the development of university teachers from the perspective of scholarship of teaching.

\section{References}

[1] Luo Yan, Handy Rose, Cen Yuhao. Higher Education Measurement in Internationally Comparative Perspective-NSSE - China Tool Development: Cultural Ad- 
aptation and Reliability, Validity Report[J]. Fudan Education Forum, 2009,7(5): 12-18.

[2] BOYER E. Scholarship Reconsidered: Priorities for the Professoriate [M].New Jersey: University Press, 1990:24.

[3] SHULMAN L S. Taking Learning Seriously [C]// HUTCHINGS P(Ed.).Teaching as Community Property: Essays on Higher Education. San Francisco, CA: Jossey-Bass, 2004:33-48.

[4] R Rice.Towards a Broader Conception of Scholarship:The American Context[A].T Whiston,R Geiger(Eds.).Re-search and higher education:The United Kingdom and the United States[M].Buckingham:SRHE and Open University Press, 1992.

[5] MCKINNEY K. Enhancing Learning through the Scholarship of Teaching and Learning[M].San Francisco,CA:Jossey-Bass, 2007.

[6] Zhou Guangli, Ma Haiquan. Scholarship of Teaching: A New Framework of Faculty Development and Evaluation[J]. Educational Research, 2013 (8): 37-47.

[7] Yang Chao, Xu Feng. University Teachers' Professional Development and its Paths from the Perspective of Scholarship of Teaching[J]. Modern Education Science: Higher Education Research, 2012 (1): 1-4.

[8] Shi Qiaojun, Zhang Xiwei. The Growth Paths of Academic Teachers - Based on the Perspective of Scholarship of Teaching[J]. Modern Enterprise Education, 2011, 2: 088.
[9] Huang Xiaomin. University Professional Development and System Study Perspective on Teaching Scholarly[D]. Shandong Economic University, 2011:14-24.

[10] Chen Xijian. On the Logic of Professional Development of University Teachers in Academic Perspective[J]. Educational Research, 2011 (8): 81-84.

[11] Liu Guilian. The Scholarship of Teaching: the Importance Perspective of University Teachers' Professionalization[J]. Educational Research and Experiment, 2009 (4): 41-43.

[12] Yao Limin. The Scholarship of Teaching and Learning and its Value[J]. Journal of Hebei University of Science and Technology: Social Science, 2010 (4): 102-106.

[13] Wang Guilin. Scholarship of Teaching: Basic Choice of Teacher's Development of Teaching-oriented University[J]. Higer Education of Engineering Research, 2012, 19(3): 103-107.

[14] Fan Zeheng. Technical Options and Strategies to Enhance the University Teachers' Teaching ability [J]. Higher Education Research, 2009, 8: 89-94.

[15] Wei Ge. Scholarship of Teaching at first-class Universities in China: an Empirical Study on Peking University[J]. Fudan Education Forum, 2014, 12(2): 34-40.

[16] Yang Chao. Exploration of Vocational Colleges' Scholarship of Teaching Issues[J]. Chinese Vocational and Technical Education, 2013 (17): 44-49. 